\title{
Efficiency of Marine Dry Fish Marketing in Bangladesh: A Supply Chain Analysis
}

\author{
Md. Mojammel Haque ${ }^{1 *}$, Md. Golam Rabbani ${ }^{2}$ and Md. Kamrul Hasan ${ }^{3}$ \\ ${ }^{1}$ Graduate Training Institute, Bangladesh Agricultural University, Mymensingh; ${ }^{2}$ Deptartment of \\ Economics, Hajee Mohammad Danesh Science and Technology University, Dinajpur; ${ }^{3}$ Spices \\ Research Center, Bangladesh Agricultural Research Institute, Shibgonj, Bogra, Bangladesh
}

*Corresponding author and Email: mojammel_haque@yahoo.com

Received: 15 February $2015 \quad$ Accepted: 06 June 2015

\begin{abstract}
The marine dried fishes have the demand both in domestic and international market. Bangladesh has a great potentiality to earn huge foreign exchange by exporting marine dry fishes. The present study was designed to analyze the supply chain and to examine marketing efficiency of marine dry fish in Bangladesh. Data were collected from 170 stakeholders and 9 export oriented firms/agencies using face to face semi-structured interviews considering 9 major species of marine fishes. A number of FGDs were conducted to supplement the information collected through survey method. The study areas were purposively selected. Three types of market such as primary market, secondary market and consumer market were considered for data gathering. High priced fish demanded high marketing cost resulting higher marketing margin and profit compared to low priced fish. Processing and transportation costs were also higher for high valued species compared to the low valued ones. Marketing margin and marketing profit were very high in export market compared to domestic market. However, shorter supply chains (channels) were more efficient than longer supply chains.
\end{abstract}

Keywords: Marine dry fish, marketing efficiency, supply chain, Bangladesh

\section{Introduction}

Traditionally, people of Bangladesh like to eat fresh fish. Chilled and dried fishes are also marketed now a days in large quantities in the towns and cities. About 20 percent of total marine catch has been dried round the year with the substantial production during October to April that sell in both domestic and international market (Shamsuddoha, 2007). Utilization and marketing distribution of fish is around $70 \%$ fresh fish, $25 \%$ dried, and the other forms of locally processed fish include fermented products and frozen products (Islam et al., 2006).
Drying of marine fishes is widespread in the coastal areas of Bangladesh and these dried fishes have the demand both in domestic and international market though the people involved early in the value chain (fishing and drying) added relatively little value and made little profit. The reasons for this less value addition at small-scale producer level are assumed to be the poor product quality and lack of market access due to various institutional and non-institutional barriers e.g. high transportation cost/ toll/ taxation, price exploitative market players between producers and consumers etc. 
The export market of value added products is highly competitive, involving changes in type of products, forms and packaging as well as consumer behaviour. Export of fish, shrimp and other fishery products were non-conventional items before the independence of the country. It has increased many-fold during the last decade and the country earned foreign exchange to minimize the balance of trade gap. Bangladesh earned Tk 4,703.95 crore by exporting fish and fisheries products during 2011-12 (DoF, 2013). In this case the dried brackish water and marine fish, the marine fin-fish and organism even other than fish, could be on the top of the list of export earning items (Kamal, 1994; Hasan, 2001). Fisheries sector earns huge foreign exchange by exporting frozen shrimp and other fish and fisheries products to the USA, UK, Japan, France, Hong Kong, Singapore, the Kingdom of Saudi Arabia, Sudan and other countries. Bangladesh earns a remarkable amount of foreign exchange every year by exporting brackish water and marine fisheries products. Due to increase in demand and high price of fishes both in domestic and export market, Bangladesh has a great potentiality to gain huge foreign exchange by exporting brackish water and marine fishes.

Data from FAO show that there is increased global trade in fisheries with the developing countries contributing $55 \%$ of the traded fishery products in 2002 (Vannuccini, 2004). This has provided the opportunity for substantial income growth. However, most countries are still faced with a challenge of how to participate in the global process in a way that provides for sustainable income growth for the poor people and for poor countries. A traditional food industry value chain consists of the producer, processor, wholesaler, exporter, importer, retailer and consumer. Analysis of value chains requires detailed micro-level data, which are not available in Bangladesh and are often difficult to obtain in most countries.

The present study takes the first steps to collect primary data and to identify the marketing channels and value addition of marine dry fishes in Bangladesh. Value chain analysis can be used to determine those factors, which drive the distribution of gain from globalization, gauge the extent to which the local people and the country are gaining from economic integration into global market products and make it easier to identify policies that can be implemented for individual producers and countries to increase their share of these gains (Kaplinsky and Morris, 2000). A number of researches (Sabur and Rahman, 1977; Ahmed et al., 1993; Islam, 1996; DFID, 2000; Islam, 2000; Islam et al., 2001; Kleih, 2001; Ghosh, 2004; Reza et al., 2004; Salam et al., 2004; Chowdhury, 2010) were conducted on marine fresh and frozen fish marketing in Bangladesh but it was very few on the dry fish. Considering marine dry fish production and distribution, it is an urgent need to study on marine dry fish marketing. The present study was therefore designed to examine how market intermediaries operate along marine dry fish value chains, and to measure the marketing efficiency of marine dry fish in Bangladesh.

\section{Materials and Methods}

\subsection{Area selection, data source and collection}

Primary data were collected for the present study to examine the supply chain and marketing efficiency of marine dry fish in Bangladesh. Afield survey as well as FGD was conducted for the year 2013 to have detailed information about marketing system of marine dry fish. The major species of selected marine dry fishes were pomfret, bombay duck, ribbon fish, jew fish, coral, paisa, surma, captured shrimp and bommaitta. A semi-structured interview schedule and a set of FGD checklist were prepared for data collection. Primary data were collected by survey method and FGD wherein marine dry fish producers, concerned traders and buyers were interviewed at various steps of marine dry fish marketing.

The study areas were selected purposively from Cox's Bazar, Chittagong, Dhaka, Mymensingh and Rangpur districts where the processing and 
marketing of marine dry fish are actively operated. Three types of market such as primary market, secondary market and consumer market were selected. A number of market intermediaries such asdry fish processors, faria, bepari, local aratder, inter-district aratder and retailer are available in marine dry fish market under the coastal areas of Bangladesh. Marine dry fish are also available in different city fish market where mainly the consumers purchase fish from the retailers. The total number of samples depends on the number of intermediaries involved in the marketing channel. Considering the scale of involvement of different kinds of intermediaries, a total of 170 samples were selected of which dry fish producers (fish drying yard owner) were 20, farias 48, beparis 40, local aratders 16, inter district aratders 16 and retailers 30. Data and information were collected from 9 export oriented firms and agencies. Moreover, a total of 9 major species of marine dry fish were considered to examine the marketing system, marketing efficiency and supply chain.

\subsection{Analytical technique}

The collected data and information were coded, tabulated, compiled and analyzed considering to the objectives of the study. Data were analyzed using SPSS and Excel. Tables and flow diagrams were prepared using arithmetic mean, percentage and ratio. An overview of the study design is presented in Figure 1, which illustrates the supply chain, value chain and value addition to marine dry fish.

\subsection{Marketing efficiency}

Marketing efficiency is a complicated topic to be defined. It carries different meanings to different persons. Four methods like i) Shephred Method ii) Acharya and Agarwal Method iii) Composite Index Method and iv) Marketing Efficiency Index Method are usually used to calculate the marketing efficiency. However, Composite Index Method was used to calculate the marketing efficiency because data and information so collected permitted study to use this method only.

\subsection{Measuring marketing efficiency}

Efficient marketing plays an important role in increasing the producer's share in consumer's spending amounted taka and maintains the tempo of increased production. Thamizhselvan and Murugan (2012) used three performance indicators for measuring the efficiency of marketing channels. These indicators are: (i) marketing cost; (ii) marketing margin and (iii) percentage of producer's share. These three indicators were also used in this study for measuring efficiency in different marketing channels. Other three indicators such as consumer's price, price variability and price deviation were not used for the present study.

2.4.1. Marketing cost: Marketing cost is the sum of transportation cost, storage cost, labour cost and other costs associated with the moving of commodity from the point of purchase to the customer or final consumer. The total marketing cost was determined by the following formula:

$T c=C p+\sum M c i$

Where, $\mathrm{i}=1, \mathrm{Tc}=$ Total cost of marketing $\mathrm{Cp}=$ Producer cost of marketing Mci $=$ Marketing cost by the ith trader

2.4.2. Marketing margin: The absolute margin of the middleman, wholesaler, trader and retailers was determined as follows:

$M m=P s a-(P b a+M c)$

Where, $\mathrm{Mm}=$ Marketing margin, $\mathrm{Psa}=$ Selling price, $\mathrm{Pba}=$ Buying price, $\mathrm{Mc}=$ Marketing cost.

The cost of marketing was calculated and the lowest cost of marketing channel was ranked I and that of other one which had the highest cost as the last. The same approach was followed in ranking the margin of middlemen in each channel.

2.4.3. Producer's share: The producer's share was derived by the ratio of net average price received by the producer to the average price of marine dry fish, which was calculated with the following formula and the channel which had highest producer's share was ranked (1) first and vice-versa. 


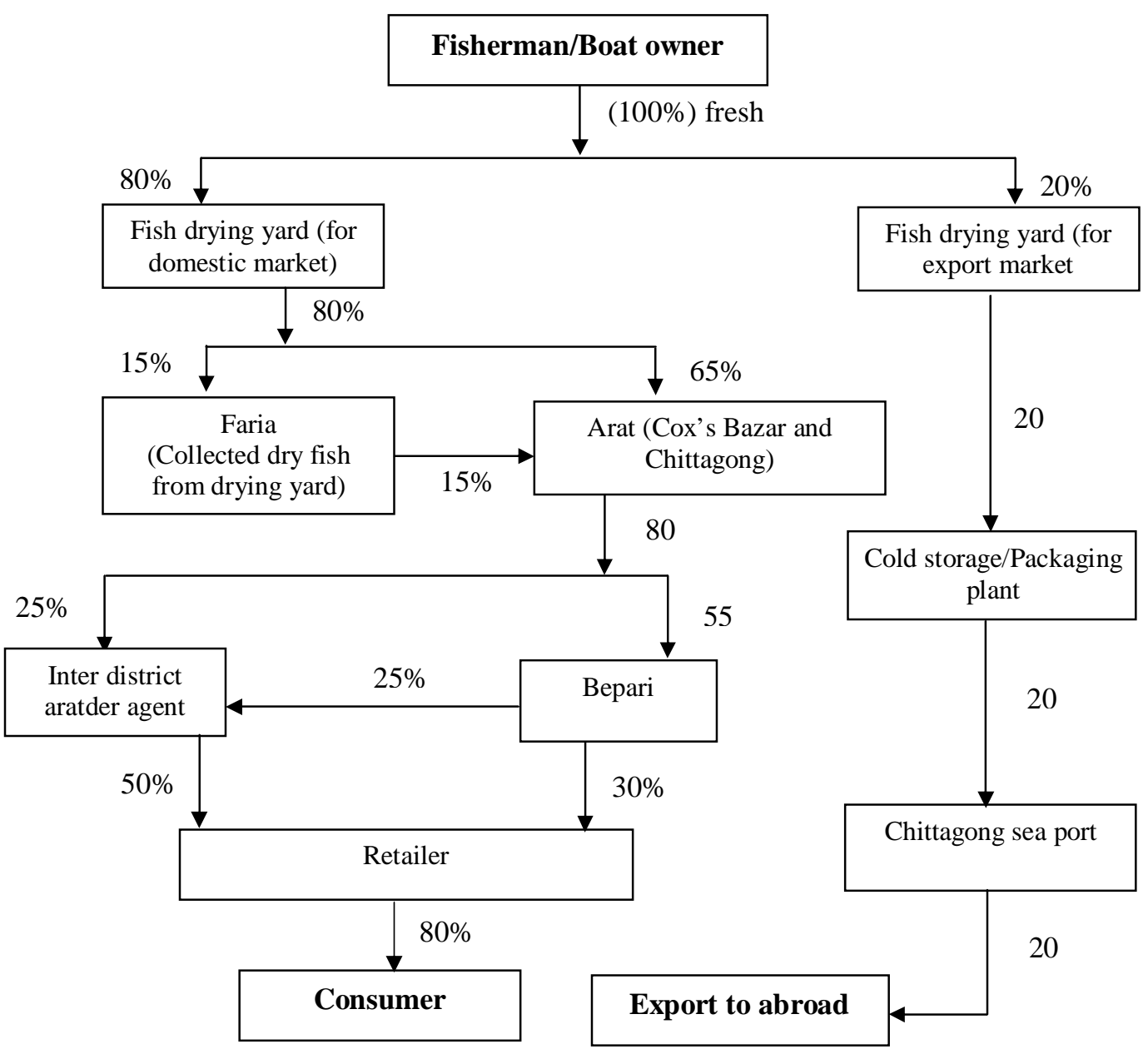

Figure 1. Supply chains of the marine dry fish marketing

Chain-1: Fish drying yard (for domestic market) $\rightarrow$ Faria $\rightarrow$ Arat $\rightarrow$ Inter district aratder agent $\rightarrow$ Retailer $\rightarrow$ Consumer $=5 \%$

Chain-2: Fish drying yard (for domestic market) $\rightarrow$ Faria $\rightarrow$ Arat $\rightarrow$ Bepari $\rightarrow$ Inter district aratder agent $\rightarrow$ Retailer $\rightarrow$ Consumer $=10 \%$

Chain-3: Fish drying yard (for domestic market) $\rightarrow$ Arat $\rightarrow$ Inter district aratder agent $\rightarrow$ Retailer $\rightarrow$ Consumer $=10 \%$

Chain-4: Fish drying yard (for domestic market) $\rightarrow$ Arat $\rightarrow$ Bepari $\rightarrow$ Inter district aratder agent $\rightarrow$ Retailer $\rightarrow$ Consumer $=25 \%$

Chain-5: Fish drying yard (for domestic market) $\rightarrow$ Arat $\rightarrow$ Bepari $\rightarrow$ Retailer $\rightarrow$ Consumer $=30 \%$

Chain-6: Fish drying yard (for export market supply) $\rightarrow$ Cold storage/packaging plant $\rightarrow$ Chittagong sea port $\rightarrow$ Export abroad $=20 \%$ 
Percentage of producer's share $=\frac{\mathrm{P}_{\mathrm{pi}}}{\mathrm{P}_{\mathrm{ri}}} \times 100$

Where, $\mathrm{P}_{\mathrm{pi}}=$ Producer's share in the ith channel, $\mathrm{P}_{\mathrm{ri}}=$ Average price at the retail level in each channel, $\mathrm{i}=$ Number of channels $(\mathrm{i}=1,2 \ldots \ldots \ldots, \mathrm{n})$.

\subsection{Composite index method}

As per this method, the percentage of producer's price, marketing cost and marketing margin to consumer's price per kg of marine dry fish were calculated and these were assigned in ranking. Total scores were found by adding the respective ranks in each channel. The mean scores were calculated for each channel. Less mean score leads the more efficient channel (Thamizhselvan and Murugan, 2012).

$$
R=\frac{R_{i}}{N_{i}}
$$

Where, $\mathrm{R}_{\mathrm{i}}=$ Total value of ranks of all indicators $\left(\mathrm{I}_{1}, \mathrm{I}_{2}\right.$ and $\left.\mathrm{I}_{3}\right), \mathrm{N}_{\mathrm{i}}=$ Number of indicators.

\section{Results and Discussion}

Table 1 shows that in domestic marketing, marine dry fish producers sold fishes mainly to beparis $(69 \%)$ via aratder and $19 \%$ to faria and $12 \%$ to inter-district aratder agent. On the other hand, specially for export marketing, marine dry fish producers sold entire amount $(100 \%)$ to fish drying factories/ processing plants. Again, faria purchased $100 \%$ fish from fish drying yard for domestic marketing and sold their fishes to bepari $(67 \%)$ and inter-district aratder agents (33\%) via aratder (Table 1). Local baparis in domestic market purchased $82 \%$ of their fishes from fish drying yard and only $18 \%$ from faria via aratder, and they sold $45 \%$ directly to retailers. On the other hand, inter-district aratder agents purchased mainly from fish drying yard (20\%), faria (30\%) and bepari (50\%) via aratders, and they sold $100 \%$ to retailers.

\subsection{Marketing cost of marine dry fish in domestic market}

Item wise costs of drying factories included loading and unloading, transportation, wage and salaries of staff and use of processing materials. Owners of drying fish factories incurred about $30 \%$ total marketing cost (Table 2). Their main cost items are wage and salaries paid to factory labourers; transportation, loading and unloading; using salt and baskets; paying bills for house rent; electricity and telephone. In comparison to frozen fish marketing, intermediaries involved in dry fish marketing incur more costs since the fish to be marketed are dried up and processed to sell it in good and hygienic condition. In the present study, estimated cost per $\mathrm{kg}$ of dried fish for beparies, inter-district aratder agent and retailers was Tk $7.83,8.78$ and 7.32 respectively (Table 2). Owners of fish drying factories spent the highest amount (Tk 13.79/kg) for fish drying and processing.

Table 3 shows species-wise marketing cost incurred in different locations in the study areas under primary, secondary and consumer market. Table reveals that there was small variation of marketing cost of different species of marine dry fish in domestic market in different location in three different levels of market. Considering all species as shown in Table 3, marketing cost was the highest (Tk 19.50/kg) in Chittagong in primary market and the lowest in Moheskhali (Tk $17.16 / \mathrm{kg}$ ). In the secondary and consumer markets, variation of marketing costs was relatively larger and wider. Both for secondary and consumer market, marketing cost was the highest in Rangpur followed by Dhaka and Chittagong. Considering all species, per $\mathrm{kg}$ marketing cost was Tk 18.06, 11.24 and 16.96 for primary, secondary and consumer market respectively.

Among the species selected for dry fish marketing, small variation was observed regarding marketing cost incurred in different levels of market (Table 3). For all kinds of market, pomfret had the highest cost followed by catfish, bombay duck, ribbon fish and surma. It seems that high valued fish claimed higher amount of marketing cost compared to other fish studied. 
Table 1. Percent of marine dry fish transacted by value chain actors

\begin{tabular}{|c|c|c|c|c|c|c|c|c|c|c|c|c|}
\hline \multirow{2}{*}{$\begin{array}{l}\text { Value } \\
\text { chain actor }\end{array}$} & \multicolumn{6}{|c|}{ Purchase from (\%) } & \multicolumn{6}{|c|}{ Sold to $(\%)$} \\
\hline & 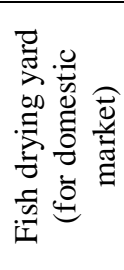 & 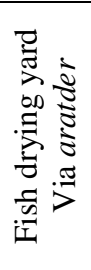 & 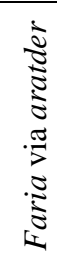 & 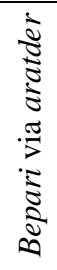 & 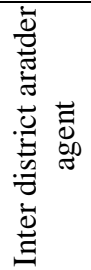 & 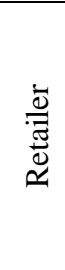 & 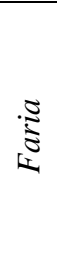 & 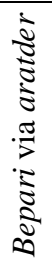 & 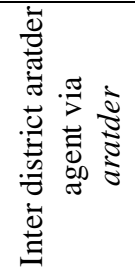 & 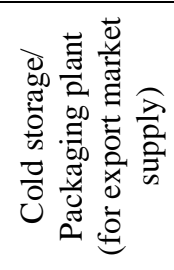 & 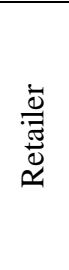 & 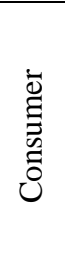 \\
\hline $\begin{array}{l}\text { Fish drying } \\
\text { yard (for } \\
\text { domestic } \\
\text { market) }\end{array}$ & - & - & - & - & - & - & 19 & 69 & 12 & - & - & - \\
\hline $\begin{array}{l}\text { Fish drying } \\
\text { yard } \\
\text { (for export } \\
\text { market) }\end{array}$ & - & - & - & - & - & - & - & - & - & 100 & - & - \\
\hline Faria & 100 & - & - & - & - & - & - & 67 & 33 & - & - & \\
\hline Aratder & \multicolumn{12}{|c|}{$\begin{array}{l}\text { Aratders negotiate between buyers and sellers of fish and help them at their own } \\
\text { business premises on receipt of Aratderi commission. }\end{array}$} \\
\hline Bepari & - & 82 & 18 & - & - & - & - & - & 45 & - & 55 & - \\
\hline $\begin{array}{l}\text { Inter } \\
\text { district } \\
\text { aratder } \\
\text { agent }\end{array}$ & - & 20 & 30 & 50 & - & - & - & - & - & - & 100 & - \\
\hline Retailer & - & - & - & 37 & 63 & - & - & - & - & - & - & 100 \\
\hline Consumer & - & - & - & - & - & 100 & - & - & - & - & - & - \\
\hline
\end{tabular}

Source: Field survey, 2013.

\subsection{Marketing cost of marine dry fish in exporting}

There are 129 processing plants (DoF, 2005) and 20 drying factories in Bangladesh. Most of the plants are situated in Cox's Bazar, Chittagong and Khulna. These processing plants process both marine and fresh water fish for export. Marketing cost increases if they have insufficient supply of fish for their plant. In that case processing plants have to gather fish from other sources and even sometimes they collect fish from other plants. When required quantities of processed fish are stocked, the processors usually export fish. In the present study selected species of dry fish exported were considered for supply chain analysis. Cost items of export firms for exporting marine dry fish are shown in Table
4. The processing plant (or export firms/ agencies) incurred cost $\mathrm{Tk} 98.64$ per $\mathrm{kg}$ for exporting marine dry fish (Table 4). However, wage and salaries of employees, packaging, freight and transportation were the main items of marketing cost for export marketing.

\subsection{Marketing margin and profitability of marine dry fish}

3.4.1. Domestic marketing

Marketing margins and profitability of different intermediaries for marine dry fish were estimated and shown in Table 5. Results were presented for individual species and average of all selected species and finally, total marketing margin and marketing profit were estimated for easy understanding and presentation. 
Table 2. Total marketing cost of intermediaries involved in major species of marine dry fish (Tk/kg) in domestic market

\begin{tabular}{|c|c|c|c|c|c|c|c|}
\hline Cost items & 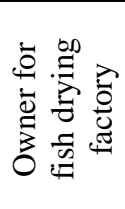 & $\frac{\sqrt{2}}{\sqrt[5]{5}}$ & 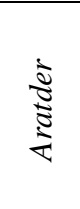 & 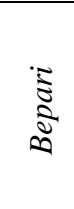 & 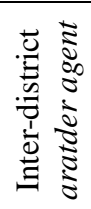 & 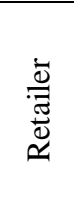 & 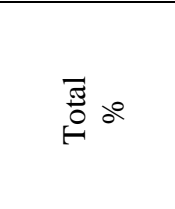 \\
\hline Cost of Machan & 0.2 & 0 & 0 & 0 & 0 & 0 & $0.20(0.45)$ \\
\hline $\begin{array}{l}\text { Transportation, } \\
\text { loading and unloading }\end{array}$ & 1.50 & 1.20 & 0.00 & 2.50 & 2.80 & 1.70 & $9.70(21.59)$ \\
\hline Salt & 1.09 & 0.00 & 0.00 & 0.00 & 0.00 & 0.00 & $1.09(2.43)$ \\
\hline Packaging & 1.25 & 0.45 & 0.00 & 1.50 & 2.10 & 1.60 & $6.90(15.36)$ \\
\hline Baskets & 0.45 & 0.35 & 0.00 & 0.48 & 0.52 & 0.45 & $2.25(5.01)$ \\
\hline Wage and salaries & 6.25 & 0.30 & 0.20 & 0.35 & 0.40 & 0.35 & $7.85(17.47)$ \\
\hline Aratder's commission & 0.32 & 0.32 & 0.32 & 0.32 & 0.32 & 0.32 & $1.92(4.27)$ \\
\hline House rent & 0.52 & 0.00 & 0.35 & 0.35 & 0.32 & 0.42 & $1.96(4.36)$ \\
\hline Security & 0.20 & 0.00 & 0.28 & 0.34 & 0.30 & 0.38 & $1.50(3.34)$ \\
\hline Electricity & 0.31 & 0.00 & 0.32 & 0.31 & 0.34 & 0.32 & $1.60(3.56)$ \\
\hline Telephone bill & 0.35 & 0.32 & 0.38 & 0.36 & 0.32 & 0.32 & $2.05(4.56)$ \\
\hline Personal expenses & 0.28 & 0.30 & 0.35 & 0.32 & 0.31 & 0.34 & $1.90(4.23)$ \\
\hline Tips and donation & 0.35 & 0.37 & 0.40 & 0.34 & 0.36 & 0.38 & $2.20(4.90)$ \\
\hline Wastage & 0.40 & 0.35 & 0.00 & 0.33 & 0.34 & 0.36 & $1.78(3.97)$ \\
\hline Others & 0.32 & 0.31 & 0.34 & 0.33 & 0.35 & 0.38 & $2.03(4.52)$ \\
\hline Total & $\begin{array}{c}13.79 \\
(30)\end{array}$ & $\begin{array}{l}4.27 \\
(10)\end{array}$ & $\begin{array}{c}2.94 \\
(7)\end{array}$ & $\begin{array}{l}7.83 \\
(17)\end{array}$ & $\begin{array}{l}8.78 \\
(20)\end{array}$ & $\begin{array}{l}7.32 \\
(16)\end{array}$ & $44.93(100)$ \\
\hline
\end{tabular}

Source: Field survey, 2013.

Note: Figures within parenthesis indicate percent of total marketing cost.

In respect of market margin and profitability of intermediaries involved at different levels of market, there is variation in different market scenario of dry fish marketing. Table 5shows that like individual species, marketing margin as well as marketing profit both were relatively higher in consumer market followed by primary and secondary markets where beparis and aratders are involved. It is evident that high priced fish demanded high marketing cost resulting higher marketing margin and profit compared to low priced fish. It was reported that processing and transportation costs were higher for high valued species compared to the low valued ones. It may be due to the processors in primary market who received lower marketing profit than retailers and aratders in consumer market and secondary market, respectively. However, considering all the selected species, total marketing margin and profit per $\mathrm{kg}$ were $\mathrm{Tk}$ 282.09 and 235.82, respectively (Table 5).

In the marketing system, although intermediaries provide services and marketing facilities and incur cost for them, but still marketing margin and profit in different levels of market were rather higher. From Tables, it can be seen that if purchase price of primary market and sales price of consumer market are considered, fishermen received $69.86-72.06 \%$ of total final price (sales revenue) for marine dry fish in domestic marketing. 
Table 3. Marketing cost of major species of marine dry fishes in domestic market in different locations (Tk/kg)

\begin{tabular}{|c|c|c|c|c|c|c|c|c|c|c|}
\hline \multirow{2}{*}{$\begin{array}{c}\text { Particular of } \\
\text { marketing }\end{array}$} & \multicolumn{10}{|c|}{ Species of fish } \\
\hline & Pomfret & Cat fish & $\begin{array}{c}\text { Bombay } \\
\text { duck }\end{array}$ & $\begin{array}{l}\text { Ribbon } \\
\text { fish }\end{array}$ & Coral & Paisa & Surma & $\begin{array}{l}\text { Captured } \\
\text { shrimp }\end{array}$ & $\begin{array}{l}\text { Bomb } \\
\text { maitta }\end{array}$ & $\begin{array}{c}\text { All } \\
\text { species }\end{array}$ \\
\hline \multicolumn{11}{|l|}{ Primary Market } \\
\hline Cox's Bazar & 18.89 & 18.48 & 18.27 & 17.80 & 17.75 & 17.69 & 18.06 & 17.80 & 17.83 & 18.06 \\
\hline Teknaf & 17.50 & 16.90 & 16.80 & 16.68 & 16.70 & 16.54 & 16.92 & 16.52 & 16.68 & 16.80 \\
\hline Moheskhali & 17.80 & 17.60 & 17.40 & 16.90 & 16.90 & 16.85 & 17.20 & 16.85 & 16.98 & 17.16 \\
\hline Chittagong & 20.50 & 19.90 & 19.70 & 19.58 & 19.25 & 19.15 & 19.30 & 19.12 & 19.04 & 19.50 \\
\hline Khulna & 20.60 & 20.20 & 19.50 & 18.20 & 18.02 & 17.80 & 18.74 & 17.98 & 18.01 & 18.78 \\
\hline Average & 19.06 & 18.62 & 18.33 & 17.83 & 17.72 & 17.61 & 18.04 & 17.65 & 17.71 & 18.06 \\
\hline \multicolumn{11}{|c|}{ Secondary Market } \\
\hline Cox's Bazar & 11.35 & 10.66 & 10.56 & 10.30 & 10.26 & 10.19 & 10.13 & 10.10 & 10.38 & 10.44 \\
\hline Teknaf & 9.95 & 9.78 & 9.60 & 9.68 & 9.72 & 9.70 & 9.69 & 9.68 & 9.58 & 9.71 \\
\hline Moheskhali & 10.04 & 9.95 & 9.88 & 9.91 & 9.98 & 9.89 & 9.88 & 9.87 & 9.86 & 9.92 \\
\hline Chittagong & 11.56 & 11.41 & 11.30 & 11.28 & 11.23 & 11.21 & 11.20 & 11.17 & 11.15 & 11.28 \\
\hline Khulna & 11.22 & 11.23 & 11.10 & 10.88 & 10.76 & 10.69 & 10.65 & 10.62 & 10.58 & 10.86 \\
\hline Dhaka & 13.50 & 13.12 & 12.97 & 12.82 & 12.86 & 12.88 & 12.92 & 12.81 & 12.86 & 12.97 \\
\hline Rangpur & 14.45 & 13.54 & 13.44 & 13.39 & 13.41 & 13.37 & 13.42 & 13.39 & 13.40 & 13.53 \\
\hline Average & 11.72 & 11.38 & 11.26 & 11.18 & 11.17 & 11.13 & 11.13 & 11.09 & 11.11 & 11.24 \\
\hline \multicolumn{11}{|l|}{ Consumer Market } \\
\hline Cox's Bazar & 17.14 & 16.10 & 15.95 & 15.55 & 15.49 & 15.38 & 15.30 & 15.25 & 15.57 & 15.75 \\
\hline Teknaf & 15.02 & 14.70 & 14.49 & 14.62 & 14.68 & 14.65 & 14.63 & 14.62 & 14.47 & 14.65 \\
\hline Moheskhali & 15.16 & 15.03 & 14.92 & 14.96 & 14.95 & 14.93 & 14.92 & 14.90 & 14.88 & 14.96 \\
\hline Chittagong & 17.45 & 17.23 & 17.06 & 17.03 & 16.96 & 16.93 & 16.81 & 16.87 & 16.72 & 17.01 \\
\hline Khulna & 16.94 & 16.83 & 16.76 & 16.43 & 16.25 & 16.14 & 16.08 & 16.04 & 15.98 & 16.38 \\
\hline Dhaka & 20.39 & 19.81 & 19.58 & 19.35 & 19.41 & 19.45 & 19.41 & 19.34 & 19.31 & 19.56 \\
\hline Rangpur & 21.62 & 20.45 & 20.29 & 20.22 & 20.25 & 20.19 & 20.26 & 20.21 & 20.23 & 20.41 \\
\hline Average & 17.67 & 17.16 & 17.01 & 16.88 & 16.85 & 16.81 & 16.77 & 16.75 & 16.74 & 16.96 \\
\hline
\end{tabular}

Source: Field survey, 2013. 
Table 4. Cost of export firms for exporting marine dry fish

\begin{tabular}{lc}
\hline Cost items & Amount $(\mathrm{Tk} / \mathrm{kg})$ \\
\hline Transportation, loading and unloading & 6.25 \\
Baskets & 6.20 \\
Wage and salaries & 15.30 \\
Electricity & 0.25 \\
Medicine and salt & 10.12 \\
Telephone bill & 0.25 \\
Personal expenses & 0.32 \\
Packaging for export & 17.14 \\
Storage & 4.40 \\
Commission paid* & 5.60 \\
Freight & 20.13 \\
Wastage & 0.50 \\
Others & 12.18 \\
\hline Total & 98.64 \\
\hline
\end{tabular}

Source: Field survey 2013.

Note: *Cost incurred for commission paid to supplier, charges of clearing and forwarding, shipment etc.

\subsubsection{Export marketing}

Table 6 shows that marine dry fish exporters obtained marketing profit of Tk 115.52 per $\mathrm{kg}$ by exporting five different species of fish. Marketing profit per kg was found to vary with species viz. Tk 44.49/kg for bombay duck to Tk 242.94 for pomfret.

In dried fish export marketing, jew fish is the most important species followed by pomfret, coral, bombay duck and surma. There was a big difference of purchase price between pomfret and other species selected and accordingly their marketing profits also differ in a large scale. By exporting the pomfret, exporters earned profit of Tk 242.94/kg which was the highest among the species exported. Moreover, it can be noticed from Table 6 that usually the high valued species of fish are exported which also claimed higher cost for its processing and marketing. But again, marketing margin and marketing profit were very high and the exporters received about $86 \%$ of the total final price (sales revenue) for marine dry fish in the export market.

\subsection{Value chain analysis of marine dry fish products}

A value chain is the full range of activities that are required to bring a product or service from its conception to the final consumers. This includes activities such as design, production, marketing, distribution and support services to the final consumer.

The price of a fish comprises cost and profits that can be analyzed to estimate value added for the purpose of comparing economic contributions and productivities between sectors of each fishery and among fisheries. Each level of market through retailing adds value to the fish product. Recently due to declines in stocks, fish processors are reshaping their production, moving to value-added products. Value is added by reducing costs and careful selection and handling of raw materials, assurance of reliable supply, meticulous packaging and presentation, careful transportation, and prompt delivery. These usually require investments in market research and in building relationships throughout the supply chain. However, to make the value chain analysis simple and understandable, value chain of dry fish is presented in Figure 2. 
Table 5. Marketing margin and profitability of marine dry fish in domestic market

\begin{tabular}{|c|c|c|c|c|c|c|c|c|c|c|}
\hline \multirow[b]{2}{*}{ Particulars of marketing } & \multicolumn{10}{|c|}{ Major species (Tk/kg) } \\
\hline & Pomfret & Cat fish & $\begin{array}{c}\text { Bombay } \\
\text { duck }\end{array}$ & $\begin{array}{l}\text { Ribbon } \\
\text { fish }\end{array}$ & Coral & Paisa & Surma & $\begin{array}{c}\text { Captured } \\
\text { shrimp }\end{array}$ & $\begin{array}{l}\text { Bomb } \\
\text { maitta }\end{array}$ & $\begin{array}{c}\text { All } \\
\text { species }\end{array}$ \\
\hline \multicolumn{11}{|l|}{ Primary market } \\
\hline Purchase price(PP) & 2275.25 & 465.25 & 315.97 & 360.77 & 1262.60 & 392.76 & 410.72 & 285.69 & 502.44 & 696.83 \\
\hline Marketing cost (MC) & 19.06 & 18.62 & 18.33 & 17.83 & 17.72 & 17.61 & 18.04 & 17.65 & 17.71 & 18.06 \\
\hline Sales price $(\mathrm{SP})$ & 2548.28 & 521.08 & 353.89 & 404.06 & 1414.11 & 439.89 & 460.01 & 319.97 & 562.73 & 780.45 \\
\hline Marketing margin (MM=SP-PP) & 273.03 & 55.83 & 37.92 & 43.29 & 151.51 & 47.13 & 49.29 & 34.28 & 60.29 & 83.62 \\
\hline Marketing profit (MP=MM-MC) & 253.97 & 37.21 & 19.59 & 25.46 & 133.79 & 29.52 & 31.25 & 16.63 & 42.58 & 65.56 \\
\hline \multicolumn{11}{|l|}{ Secondary market } \\
\hline Purchase price(PP) & 2548.28 & 521.08 & 353.89 & 404.06 & 1414.11 & 439.89 & 460.01 & 319.97 & 562.73 & 780.45 \\
\hline Marketing cost (MC) & 11.72 & 11.38 & 11.26 & 11.18 & 11.17 & 11.13 & 11.13 & 11.09 & 11.11 & 11.24 \\
\hline Sales price $(\mathrm{SP})$ & 2828.59 & 578.40 & 392.81 & 448.51 & 1569.66 & 488.28 & 510.61 & 355.17 & 624.63 & 866.30 \\
\hline Marketing margin (MM=SP-PP) & 280.31 & 57.32 & 38.93 & 44.45 & 155.55 & 48.39 & 50.60 & 35.20 & 61.90 & 85.85 \\
\hline Marketing profit (MP=MM-MC) & 268.59 & 45.94 & 27.67 & 33.27 & 144.38 & 37.26 & 39.47 & 24.11 & 50.79 & 74.61 \\
\hline \multicolumn{11}{|l|}{ Consumer market } \\
\hline Purchase price(PP) & 2828.59 & 578.40 & 392.81 & 448.51 & 1569.66 & 488.28 & 510.61 & 355.17 & 624.63 & 866.30 \\
\hline Marketing cost (MC) & 17.67 & 17.16 & 17.01 & 16.88 & 16.85 & 16.81 & 16.77 & 16.75 & 16.74 & 16.96 \\
\hline Sales price $(\mathrm{SP})$ & 3196.31 & 653.59 & 443.88 & 506.82 & 1773.72 & 551.76 & 576.99 & 401.34 & 705.84 & 978.91 \\
\hline Marketing margin (MM=SP-PP) & 367.72 & 75.19 & 51.07 & 58.31 & 204.06 & 63.48 & 66.38 & 46.17 & 81.20 & 112.62 \\
\hline Marketing profit (MP=MM-MC) & 350.05 & 58.03 & 34.06 & 41.43 & 187.21 & 46.67 & 49.61 & 29.42 & 64.46 & 95.66 \\
\hline \multicolumn{11}{|l|}{ Total marketing margin and profit } \\
\hline Total marketing margin & 921.06 & 188.34 & 127.91 & 146.05 & 511.12 & 159.00 & 166.27 & 115.65 & 203.40 & 282.09 \\
\hline Total marketing profit & 872.61 & 141.18 & 81.31 & 100.16 & 465.38 & 113.45 & 120.33 & 70.16 & 157.84 & 235.82 \\
\hline
\end{tabular}

Source: Field survey 2013. 
Table 6. Marketing margin and profitability of marine dry fish in export market

\begin{tabular}{lcccccc}
\hline Particulars of marketing & \multicolumn{5}{c}{ Major Species (Tk/kg) } \\
\cline { 2 - 7 } & $\begin{array}{c}\text { Jew } \\
\text { fish }\end{array}$ & Pomfret & Coral & $\begin{array}{c}\text { Bombay } \\
\text { duck }\end{array}$ & Surma & $\begin{array}{c}\text { All } \\
\text { species }\end{array}$ \\
\hline Purchase price(PP) & 528.08 & 3229.00 & 1873.14 & 437.90 & 558.39 & 1325.30 \\
Marketing cost (MC) & 99.50 & 98.60 & 98.50 & 98.36 & 98.25 & 98.64 \\
Sales price (SP) & 680.20 & 3570.54 & 2150.25 & 580.75 & 715.60 & 1539.47 \\
Marketing margin (MM=SP-PP) & 152.12 & 341.54 & 277.11 & 142.85 & 157.21 & 214.16 \\
Marketing profit (MP=MM-MC) & 52.62 & 242.94 & 178.61 & 44.49 & 58.96 & 115.52 \\
\hline
\end{tabular}

Source: Field survey 2013.

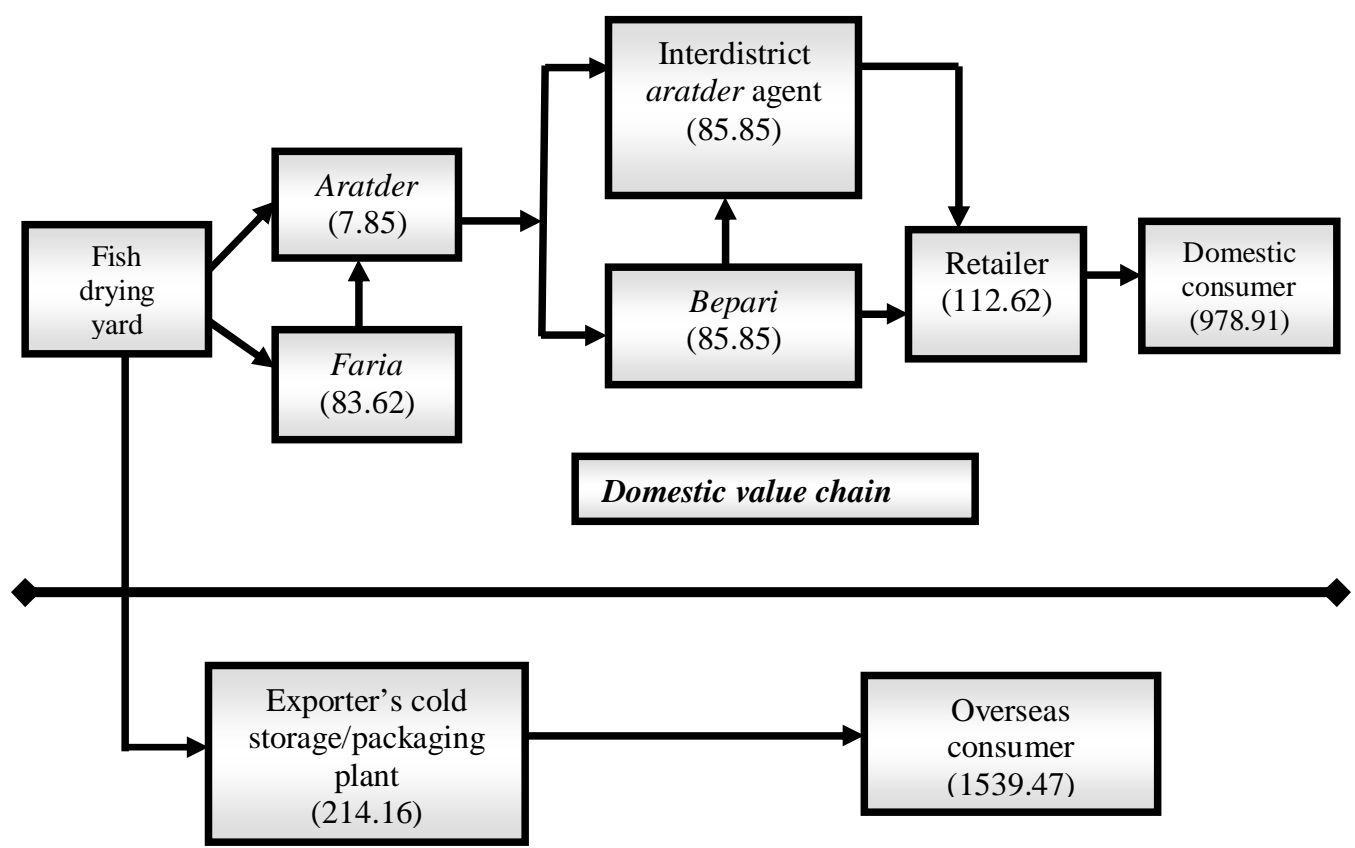

\section{Overseas value chain}

Figure 2. Value chains of dry fish in domestic and export market Source: Field survey 2013.

This value chain derived from Tables 3, 5 and 6 .

Note: Figures in the parenthesis indicate the average gross marketing margin/added value (Tk/kg) by value chain actors in primary to consumer market. Fisherman and faria are involved in primary market, aratder and bepari in secondary market, and inter-district aratder and retailer in consumer market. 
Table 7. Dry fish producer' share under different marketing channel

\begin{tabular}{lccccc}
\hline Particulars & Channel-1 & Channel -2 & Channel -3 & Channel -4 & Channel-5 \\
\hline Dry fish producer (Tk/kg) & 715.2 & 678.06 & 695.17 & 708.37 & 687.4 \\
Consumer/ retail price (Tk/kg) & 992.5 & 970.6 & 987.02 & 994.05 & 950.35 \\
$\begin{array}{l}\text { Percentage of dry fish } \\
\text { produces share (\%) }\end{array}$ & 72.06 & 69.86 & 70.43 & 71.26 & 72.33 \\
Rank (I $\left.\mathrm{I}_{1}\right)$ & II & V & IV & III & I \\
\hline
\end{tabular}

Source: Field survey 2013.

Table 8. Marketing cost and margin of different marketing channel of dry fish

\begin{tabular}{lccccc}
\hline Particulars & Channel-1 & Channel -2 & Channel -3 & Channel -4 & Channel -5 \\
\hline Dry fish producer (Tk/kg) & 715.20 & 678.06 & 695.17 & 708.37 & 687.40 \\
Consumer/ retail price (Tk/kg) & 992.50 & 970.60 & 987.02 & 994.05 & 950.35 \\
Marketing margin (Tk/kg) & 277.30 & 292.54 & 291.85 & 285.68 & 262.95 \\
Rank $\left(\mathrm{I}_{2}\right)$ & II & V & IV & III & I \\
Marketing cost (Tk/kg) & 37.27 & 44.77 & 32.72 & 40.22 & 31.79 \\
Rank $\left(\mathrm{I}_{3}\right)$ & III & V & II & IV & I \\
\hline
\end{tabular}

Source: Field survey 2013.

\subsection{Marketing efficiency of marine dry fish}

\subsubsection{Dry fish producer' share under different marketing channel}

Dry fish producer's share in consumer price was the highest in channel 5 followed by channels1, 4 and 3 and the lowest share in channel 2 (Table 7). It indicates that if dry fish producers would sell their dry fish through Fish drying yard $\rightarrow$ Arat $\rightarrow$ Bepari $\rightarrow$ Retailer $\rightarrow$ Consumer, they would be most benefited.

\subsubsection{Marketing cost and margin of different channels of marine dry fish}

Table 8 shows that the total marketing cost incurred by the various market intermediaries was the highest in channel 2 followed by Channels 4, 1 and 3 and the lowest marketing cost was in channel 5. The marketing margin was also the highest in channel 2 and minimum in channel 5.

\subsubsection{Efficiency of different marketing channels of marine dry fish}

The channel obtaining the least score is considered to be efficient under the Composite Index Method and thus, as evident from Table 9, channel 5 consisting dry fish producer, aratder, bepari, retailer and consumer which had the least score is considered the most efficient channel followed by channel 1 (Dry fish producer $\rightarrow$ Faria $\rightarrow$ Arat $\rightarrow$ Inter district aratder agent $\rightarrow$ Retailer $\rightarrow$ Consumer). The channel 2 (Dry fish producer $\rightarrow$ Faria $\rightarrow$ Arat $\rightarrow$ Bepari $\rightarrow$ Inter district aratder agent $\rightarrow$ Retailer $\rightarrow$ Consumer) was inefficient as the mean score of this channel was the maximum. 
Table 9. Marketing efficiency of dry fish under composite index method

\begin{tabular}{lcccccc}
\hline \multicolumn{7}{c}{ Score as performance indicators } \\
\hline Marketing & $\begin{array}{c}\text { Producers } \\
\text { Share }(\%) \\
\left(\mathrm{I}_{1}\right)\end{array}$ & $\begin{array}{c}\text { Marketing } \\
\text { margin }(\mathrm{Tk} / \mathrm{kg}) \\
\left(\mathrm{I}_{2}\right)\end{array}$ & $\begin{array}{c}\text { Marketing cost } \\
(\mathrm{Tk} / \mathrm{kg}) \\
\left(\mathrm{I}_{3}\right)\end{array}$ & $\begin{array}{c}\text { Total } \\
\text { score }\end{array}$ & $\begin{array}{c}\text { Mean } \\
\text { score }\end{array}$ & Rank \\
\hline Channel-1 & 72.06 & 277.30 & 37.27 & 7.0 & 2.33 & III \\
Rank & 2 & 2 & 3 & & & \\
Channel -2 & 69.86 & 292.54 & 44.77 & 15 & 5.0 & I \\
Rank & 5 & 5 & 5 & & & \\
Channel -3 & 70.43 & 291.85 & 32.72 & 10 & 3.33 & II \\
Rank & 4 & 4 & 2 & & & \\
Channel -4 & 71.26 & 285.68 & 40.22 & 10 & 3.33 & II \\
Rank & 3 & 3 & 4 & & & \\
Channel -5 & 72.33 & 262.95 & 31.79 & 3 & 1.0 & IV \\
Rank & 1 & 1 & 1 & & & \\
\hline
\end{tabular}

Source: Field survey 2013.This Table derived from Tables7 and 8.

Note: Marketing efficiency estimated by Composite Index Method.

\section{Conclusions}

The study reveals that the marine dry fish producers spent the highest amount for fish drying and processing. But marketing margins as well as marketing profit both were relatively higher in consumer market followed by primary and secondary markets where beparis and aratders are involved. There is variation in profit earned by different intermediaries in the primary and secondary markets. In this regard, primary and secondary markets should be free from the control of beparis and aratders to make the market competitive so that the marine dry fish produces could receive reasonable price to increase their sales revenue. Usually, the high valued species of marine dry fish are exported which also claimed higher cost for its processing and marketing. As a result, marketing margin and marketing profit were very high for marine dry fish in the export market. The marketing system of marine dry fish in Bangladesh is yet not developed and it is usually organized and managed by the private sector. Public sector should come forward for monitoring the marine dry fish market so that Bangladesh can earn more foreign exchange by exporting marine dry fishes.

\section{References}

Ahmed, M., Rab, M. A. and Bimbao, M. A. P. 1993. Household Socio-economic Resource Use and Marketing in two Thanas of Bangladesh. ICLARM Technical Report 04, 34 p.

Chowdhury, N. K. 2010. Input and Quality Control: A Stochastic Frontier Analysis of Bangladesh's Industrial Trawl Fishery. AARES 54th Annual Conference 10-12 February 2010.

DFID, 2000. Northwest Fisheries Extension Project-2, Livelihood Review. Livelihood Assessment of Communities and Households and Technical Assistance of Aquaculture Technologies and Methods. Vol. 1, DFID, Dhaka, June 2000.

DoF, 2005. Export of Fish and Fish Product from Bangladesh. Fish Inspection and Quality Control, Department of Fisheries, Ministry of Fisheries and Livestock, Dhaka, Bangladesh.

DoF, 2013. National Fish Week Compendium. Department of Fisheries, Ministry of Fisheries and Livestock, Dhaka, Bangladesh. 
Ghosh, S. K. 2004. Market analysis for mollusk (oyster, Crassostrea sp. green mussel, Perna viridis, clam, Meretrix meretrix) in Bangladesh through consumer survey. Bangladesh Journal of Fisheries. Special Issue, Vol. 27, June 2004.

Hasan, M. R. 2001. Demand-led research and management of wild freshwater fish in Bangladesh. Support of University Fisheries Education and Research (SUFER), Dhaka, 76 p.

Islam, M. A. 2000. Recent trends in fisheries sector of Bangladesh, in M. A. S. Mandal (ed). Changing Rural Economy of Bangladesh. Bangladesh Economic Association, Dhaka.

Islam, M. S. 1996. Manual on socio-economic analysis in aquaculture research. Fisheries Research Institute, Mymensingh.

Islam, M. S., Akteruzzaman, M. and Ahmed, N. 2006. Study on marketing and value chain of some commercially important coastal and marine aquatic products of Bangladesh. Research Report, Bangladesh Fisheries Research Forum, Dhaka, Bangladesh.

Islam, M. S., Miah, M. T. H. and Haque, M. M. 2001. Marketing system of Marine fish in Bangladesh: An Empirical Study. The Bangladesh Journal of Agricultural Economics, 24 (1\&2): 127-142.

Kamal, M. 1994. Status and prospect of value addition of marine fisheries by catch and their marketing. Proceeding of a Workshop on Sustainable Development of Marine Fisheries Resource in Bangladesh. Sinha, V. R. P., Mazid, M. A. and Kamal, M. (eds). FAO-UNDP assistance to Fisheries Research Institute, Mymensingh.

Kaplinsky, R. and Morris, M. 2000. A Handbook for Value Chain Research. International Development Research Center (IDRC). Ottawa, Canada.
Kleih, U. 2001. Fish distribution from coastal communities - market and credit issues. Workshop at the CARITAS auditorium, Chittagong, on Poverty Alleviation and Livelihood Security among the Coastal Fishing Communities, 27-28 March, 2001.

Reza, M. S., Kamal, M., Akhteruzzaman, M. and Islam, M. N. 2004. Present status of drying activities of marine fishes in the coastal region of Bangladesh. Bangladesh Journal of Fisheries. Special Issue, Vol. 27, June 2004.

Sabur, S. A. and Rahman, L. 1977. Marine Fish Marketing in Bangladesh. The Bangladesh Journal of Agricultural Economics, 2(1): 95-107.

Salam M. A., Karmoker, A., Mukta, T. A., Bain, S., Hasan, S. R. and Hossain, M. A. R. 2004. Access rights and governance that affect the coastal poor communities to harvest and culture of mollusks, shrimp PL nursing and mud crab fattening in Bangladesh coast. Bangladesh Journal of Fisheries. Special Issue, Vol. 27, June 2004.

Shamsuddoha, M. 2007. Supply and Value Chain Analysis in the Marketing of Marine Dried Fish in Bangladesh and Non Tariff Measures (NTMs) in International Trading. Paper prepared for presentation at the 106th seminar of the EAAE Montpellier, France.

Thamizhselvan, K. and Murugan S. P. 2012. Marketing of Grapes in Theni District. International Journal of Marketing and Technology, 2(9): 96-111. http://www.ijmra.us

Vannuccini, S. 2004. Overview of Fish Production, Utilization, Consumption and Trade: Based on 2002 Data. Rome: Food and Agriculture Organization of the United Nations. ftp://ftp.fao.org/fi/stat/overview/overvie w.pdf 